\title{
MAGNETIC RESULTS OF HALLEY'S EXPEDITION, 1698-1700.
}

By L. A. Bauer.

It will be recalled that the noted astronomer, Edmund Halley, in 1698, was placed by King Geonge III in command of the sailing

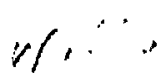

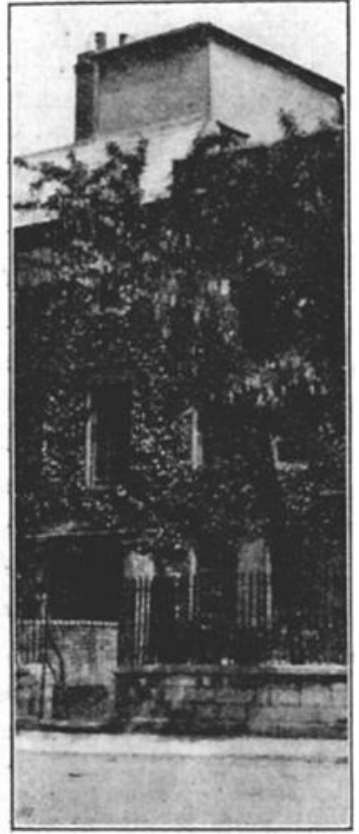

Halley's house at Oxford, showing his observatory on the roof. [View taken by L. A. Bauer. May, 1913.] ship, the Paramour Pink, for "proceeding with her on an expedition to improve the knowledge of the Longitude and variations of the Compasse." He was explicitly instructed that "in all the Course of your voyage you must be carefull to omit no opportunity of noting the variation of the Compasse, of which you are to keep a Register in your Journal." 1

Halley set out on his first voyage from Deptford on October 20,1698; returning to England towards the end of June, 1699, he sailed again from Deptford, September 16,1699 , this second voyage terminating at Long-reach, September 7, 1700. The two voyages together extended over the Atlantic Ocean from $50^{\circ} \mathrm{N}$. to about $52^{\circ} \mathrm{S}$. Halley's expedition is memorable as being the first scientific one sent out by any country with the specific object of ascerta hing the direction in which a compass sets itself at various places; it was the first ocean magnetic survey. The expedition fully justified itself, not only in the results immediately obtained, but by the impetus given to further investigation in magnetism and other subjects. It seems strange, therefore, that Halley, though a prominent member of the Royal Society, published no report on his work. He appears to have been satisfied with the graphical representation of his magnetic results as shown on his famous chart-the first successful one of its kind-giving the lines of equal magnetic declination (variation of the compass) for the year 1700 .

'Cf. Terr. Mag., v. 16, p. 124. 
It was not until 1775 that Halley's journal-the Register in which he was instructed to note the "variation of the Compasse"was published, and then by Alexander Dalrymple in his "Collection of Voyages chiefly in the Southern Atlantick Ocean." Halley's original journal was loaned to Dalrymple by the Board of Longitude. ${ }^{2}$ As this particular book by Dalrymple has now become scarce, and as Halley's observed values of the magnetic declination are either not given at all, or but incompletely, in published collections of magnetic observations, such as for example, Hansteen's, and van Bemmelen's, it was thought desirable to make them known to readers of the Journal. (See pp. 126-132.)

The occasion was embraced at the same time by the compilers, Messrs. Ault and Wallis, members of the Department of Terrestrial Magnetism, to compute additional values of the magnetic declination from Halley's observed amplitudes of the Sun, which he does not appear to have reduced, and, furthermore, to revise the geographical positions, which, at times, required considerable correction. It was found worth while to spend the additional labor thus involved in the compilation. A careful scrutiny of Halley's results, obtained in the same locality at different times and at the intersections of his various cruises, as well as at ports where other data existed, showed that, considering all circumstances, he certainly had followed his instruction to observe "the variation of the Compasse with all the accuracy you can." Indeed, his work, though his instruments had not the refinement of modern ones, will yet compare favorably with that on some of our modern iron-clads, for the reason that his ship appears to have been almost a non-magnetic one - not by reason of special design, as in the case of the Carnegie, but because of the mode of construction at the time. His results for magnetic declination-this was the only magnetic element observed-appear to be reliable, as far as the examination could extend, to within one degree and even one-half degree, or as closely as he generally observed the Sun's amplitude.

The compilation is found to contain a number of important values of the magnetic declination at Atlantic ports and islands in the Atlantic Ocean. With the aid of these values it will be possible thus to extend backwards the established expressions for the

2 Dalrymple found some portions of the Journal missing. Thus, he says, "The Journal of Dr. Halley's first Voyage is written on sundry scraps of paper, and some parts repeated in different places, and so blended that it was a very difficult matter to make it out intelligibly; I find no account at all of his departure from Barbadoes, so that there is a deficiency of a few days in this part of the voyage; and the conclusion is also wanting." 
secular variation of the magnetic declination at these places 100 150 years. At most of these places, the Carnegie and observers of the Department of Terrestrial Magnetism have recently made observations, so that the course of the secular variation can be followed here, with fair accuracy, for over two centuries.

\section{Halley's Variation Chart.}

The information as to mode of construction and date of issue of Halley's "Variation" or Isogonic ${ }^{3}$ Chart for 1700 has also been very meager. In Nature, of May 23, 1895, p. 79, I made known the finding, in the British Museum, of a Halley isogonic chart which had escaped the attention of magneticians and bibliographers. Upon seeing the notice, Thos. Ward, Esq., of Northwich, England, made known in the following issue of the same periodical the fact that he likewise possessed a copy of this Halley chart and, through his courtesy, it was possible to give in the January, 1896, issue of Terrestrial Magnetism a facsimile reproduction reduced to

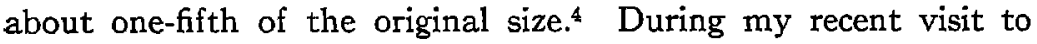
England (May-June, 1913) and in connection with the preparation of the Halley Lecture on Terrestrial Magnetism, delivered on May 22 at the University of Oxford, ${ }^{5}$ I had occasion to ascertain some additional facts regarding Halley's observations and charts.

Appendix A contains extracts pertaining to Terrestrial Magnetism from the Journals of the Royal Society, in which mention is made of Edmund Halley, during, and subsequent to, the period of Halley's voyages and the issuing of his chart. These extracts were made from the Rigaud Papers at the Bodleian Library, Oxford, the privilege of examining which, through the kind offices of Prof. A. E. H. Love, F. R. S., was courteously extended to me by the Librarian, F. Maden, M. A., to whom I wish to acknowledge here my indebtedness. Some of the more important of these extracts were later verified by me from the original records at the Royal Society in Burlington House, London, through the courtesy of the Librarian, Mr. Harrison.

Minutes 1, 2, 3, 7, 8, and 13 refer to Halley's map which "shewed the Variations of the needle." Nos. 1 and 2, as Halley's voyages

\footnotetext{
2 Halley gave no distinctive name to his lines. For some time they were referred to by others as the "Halleyan Lines." Hansteen introduced the term "isogonic."

- Cf. Terr. Mag., v, 1, Jan., 1896, pp. 28-31 and frontispiece.

- Published in Bedrock, issue of October, 1913.
} 
were not concluded until Sept. 7, 1700, refer evidently to a manuscript map, which possibly at first only covered that part of the world-the Atlantic Ocean-mbraced in his expedition. No. 3 states that "Capt. Halley produced a map wherein was the course they had held in his late voyage." Now, the only Halley map thus far known which contains the course of the Paramour Pink is the one above referred to, a copy of which, as stated, was originally found in the British Museum. ${ }^{6}$ I have termed it the "Atlantic Chart," to distinguish it from the "World Chart," apparently issued later. ${ }^{4}$

From the recent search made in the four libraries, Bodleian (Oxford), Cambridge University Library, British Museum, and Library of Congress (Washington, D. C.), I have found that a copy of this "Atlantic Chart" formed the first map in the fourth book of "The English Pilot," published by W. Mount and T. Page in London, 1737. This "fourth book" contained maps solely pertaining to the Atlantic Ocean, "describing the West-India navigation, from Hudson's Bay to the river Amazones." This copy of the Halley "Atlantic Chart" was not given in the 1706 edition of the "English Pilot." I have thus far seen it in the editions of 1737 and 1753 ; in the 1755 and subsequent editions there is a revised isogonic chart for the Atlantic without, however, now being credited to or signed by Halley.

The copy of the Halley "Atlantic Chart" in "The English Pilot" for 1737 , is precisely the same as that reproduced in this Journal,4 except for a border text printed on the two sides of the chart, giving "The Description and Uses of a New and Correct SEACHART of the Western and Southern Ocean, shewing the Variations of the Compasse," signed, E. Halley. As this text may be Halley's first description of his chart, it is given in Appendix B; it does not appear to have been printed on the margins of the chart, when published separately, but it is possible that it may have been printed on a separate sheet to be attached to the chart. No date is given on the chart; however, it was dedicated to King William III, who fitted out Halley's expedition and who died March 8, 1702; the "Atlantic Chart," when sold separately, was, therefore, issued originally prior to March 8, 1702-probably in 1701 .

Minute 7, June 4, 1701, records the presentation of Halley's map to the Society and "it was ordered to be hung in the meeting 
room." Neither this copy nor the one which Halley presented to the Society on December 8,1703 (Minute 13) could be found in the Royal Society rooms. The latter may have been Halley's more complete chart, embracing now the whole world-the "World Chart." Every copy of this Chart thus far seen by me in the libraries of Berlin, Hamburg, Paris, London, Oxford, Cambridge, and Washington is dedicated, "To His Royall Highness, Prince George of Denmark, Lord High Admirall of England, Generalissimo of all Her Majestie's Forces." Since Prince George, consort of Queen Anne, did not bear this title until April 17, 1702, the "World Chart," as far as the present evidence goes, must have been issued subsequent to this date. The earliest atlas in which I have thus far found the "World Chart" is the "Atlas Maritimus Novus or The New Sea-Atlas printed for Richard Mount and Thomas Page on Tower Hill MDCII," a copy of which was seen by me at the University Library, Cambridge, England, through the facilities courteously placed by the Librarian at my disposal, at the instance of Professor Sir Joseph Larmor, F. R. S., M. P: This atlas, as is seen, was published in 1702-probably, for the reason above givennear the middle or end of the year; Halley's "World Chart," in two sheets $\left(20^{\circ} \mathrm{W}\right.$. to $160^{\circ} \mathrm{E}$. and $160^{\circ} \mathrm{E}$. to $20^{\circ} \mathrm{W}$.), is in the front part of the Atlas.

Airy reproduced the "World Chart" in the Greenwich Observations of 1869 , as he could find no one of his day who had ever seen a copy of Halley's magnetic chart. After some search in libraries at home and abroad, he found a copy in the British Museum which was then thought to be the only copy of the original edition. ${ }^{7}$ Airy apparently was not aware of the "Atlantic Chart," and the date erroneously ascribed to the copy of the "World Chart" was 1701. Hellmann, in No. 4 of his valuable series of "Neudrucke von Schriften und Karten über Meteorologie und Erdmagnetismus," reproduced the "World Chart," making use of the photolithographic reproduction of the British Museum copy made for Airy in September, 1870. Hellmann's reprint was published

The British Museum copy used by Airy is either that catalogued as number 974. (5) or 973. (15). The name of the selling agent is not given on these two copies, and they are the orly ones thus far found in which this is the case; the size of these coples is $48 \times 20 \%$ inches. The copy in the "Atlas Maritimus, 1702," referred to above, as well as the Hamburg and Paris copies. and the copy in the Atlas containing the Mountaine and Dodson charts of 1744 and 1758, has printed in the legend over Brazil, in the free space under the year MDCC. "Sold by R. Mount and T. Page, on Great Tower Hill, London." The last three named copies have, furthermore, an extra strip pasted on the left side, embracing again the region $90^{\circ} \mathrm{E}$. to $160^{\circ} \mathrm{E}$., so that the chart extends now over $430^{\circ}$ in longitude, instead of but $360^{\circ}$. 
shortly prior to the finding of the Halley "Atlantic Chart," and so he likewise gave the date 1701 to the "World Chart." Hellmann is to be credited with being the first to bring to light and to reproduce the border text to the "World Chart" found on the copy in the Hamburg Stadtbibliothek. In Appendix C, this text ${ }^{8}$ is given as based on copies I have myself seen; the copy in Hellmann's reprint contains a few errors-possibly typographical ones in the original.

The reader will find some interesting information in the.two texts (Appendices $B$ and $\mathcal{C}$ ), as well as certain secular variation data.

\section{Halley's Declination Observations at London.}

The only values of the magnetic declination observed by Halley at London, thus far to be found in published compilations, are those given by Halley himself in his papers, in the Philosophical Transactions of 1683 and 1692 , namely, $2^{\circ} 30^{\prime} \mathrm{W}$ in $1672,4^{\circ} 30^{\prime} \mathrm{W}$ in 1683 , and $6^{\circ} 00^{\prime} \dot{W}$ in 1692 . Consulting, however, Appendix $A$, Minutes 5, 9, and 21, the following additional values are obtained, the first of which is of particular interest, as it gives some information as to the magnetic needles used by Halley on his expedition:

1701, May 7. Mr. Halley tried the experiment of the Variation of the Needle this day, with the two needles he had with hin in his late Voyage: and by the one the Variation was $7^{\circ} 40^{\prime}$, by the other $8^{\circ} 00^{\prime} \mathrm{W}$.

1702, July 8. Mr. Halley observed the Variation of the Needle, which was found to be $812^{\circ}$ Westward, or very near it.

1716, May 24. Dr. Halley reported that he had clrawn a Meridian Line on the stone erected in the Society's yard before the repository, and that the Variation was found at present to be full twelve degrees.

These additional values fall in well with those computed from the secular variation expressions established by Dr. Felgentraeger and myself on the basis of the data known at the time. ${ }^{y}$

In conclusion, the references to Halley's theory of the Aurora Borealis, contained in Appendix A, Minutes 19, 20, 22, 23, 26, and 28 , will be of interest.

"I have not yet seen in the English libraries consulted a copy of Halley's "World Chart" which contains this border text, although from the Rigaud papers at the Bodleian Library the text, or description of Halley's Chart, was at one time in the British Museum. Rigaud says that "at the bottom of the chart there is added a strip of letter press of about six inches in breadth containing what has been copied." [The same text as given in Appendix C.]

- Bauer, L. A. Beitrage zur Kenntniss des Wesens der Säcular-Variation des Erdmagnetismus, pp. 14-17. Inaug. Diss. University Berlin, 1895. 
Appendix $A$.

EXTRACTS PERTAINING TO TERRESTRIAL MAGNETISM FROM THE JOURNALS OF THE ROYAL SOCIETY, IN WHICH MEN-

TION IS MADE OF EDMUND HALLEY, JUNE 3, 1696DECEMBER 17, 1741.

\begin{tabular}{|c|c|c|}
\hline No. & Date & Minute \\
\hline 1 & $\begin{array}{l}1699 \\
\text { Aug. } 16\end{array}$ & $\begin{array}{l}\text { Mr. Halley shewed the several Variations of the Needle, } \\
\text { he had observed in his voyage, set out in a sea chart, as also } \\
\text { he shewed that Brazile was ill placed in the (ye) common Maps, } \\
\text { and he shewed some Barnacles which he observed to be of } \\
\text { quick growth. }\end{array}$ \\
\hline 2 & $\begin{array}{l}1700 \\
\text { Oct. }\end{array}$ & $\begin{array}{l}\text { Capt. Halley produced a map and shewed in it his observa- } \\
\text { tions on the Variation of the Magnetical Needle which he rec- } \\
\text { tified in the Chart, as it was curiously laid down with Marks, } \\
\text { etc., in this Map. }\end{array}$ \\
\hline 3 & Feb. $^{1701} 5$ & $\begin{array}{l}\text { Capt. Halley shewed a Map, wherein was the course they } \\
\text { had held in his late voyage, and where were noted Variations } \\
\text { of the Needle, in several parts of the world; as also the true } \\
\text { longitudes and latitudes of many places. }\end{array}$ \\
\hline 4 & Feb. $^{1701} 5$ & $\begin{array}{l}\text { There was read an Advertisement concerning the latitude } \\
\text { of the Lizard and Variation by Mr. Halley. He was thanked } \\
\text { for this Communication, which was judged very useful to the } \\
\text { public. }\end{array}$ \\
\hline 5 & $\operatorname{May}^{1701} 7$ & $\begin{array}{l}\text { Mr. Halley tried the experiment of the Variation of the } \\
\text { Needle this day, with the two needles he had with him in his } \\
\text { late Voyage: and by the one the Variation was } 7^{\circ} 40^{\prime} \text {, by the } \\
\text { other } 8^{\circ} 00^{\prime} \mathrm{W} \text {. }\end{array}$ \\
\hline 6 & $\operatorname{May}^{1701} 14$ & $\begin{array}{l}\text { Mr. Halley said that the Needle with a counterpoise, he } \\
\text { thought useful in observing the Variations in those parts of } \\
\text { the world where the needle dips, and that it observes more } \\
\text { exactly than the other sort of needle. }\end{array}$ \\
\hline 7 & $\begin{array}{l}1701 \\
\text { June }\end{array}$ & $\begin{array}{l}\text { Mr. Halley presented the Society with a Map of his late } \\
\text { Voyage (Voiage) to the South. He was thanked for it, and it } \\
\text { was ordered to be hung in the Meeting room. }\end{array}$ \\
\hline 8 & $\begin{array}{l}1702 \\
\text { June }\end{array} 17$ & $\begin{array}{l}\text { A letter was read from Dr. Wallis to Capt. Halley, con- } \\
\text { cerning his map of Magnetic Variations and some other things } \\
\text { relating to the magnet. }\end{array}$ \\
\hline 9 & July $^{1702} 8$ & $\begin{array}{l}\text { Mr. Halley observed the Variation of the Needle, which } \\
\text { was found to be } 812^{\circ} \text { Westward, or very near it. }\end{array}$ \\
\hline 10 & July $^{1702} 15$ & $\begin{array}{l}\text { Mr. Halley said, that at the first observation of the needle } \\
\text { it varied } 111 / 4^{\circ} \text { East. [Borough's and Norman's observation of } \\
1580 .- \text { L. A. B.] }\end{array}$ \\
\hline 11 & $\operatorname{May}_{1702}^{17} 27$ & $\begin{array}{l}\text { Mr. Julianus said that Dijou-a compass-in } 20 \text { years } \\
\text { had changed or varied } 8^{\circ} \mathrm{W} \text { and as much East. Mr. Halley } \\
\text { thought this alteration must have come from some iron placed } \\
\text { in the neighbourhood of the needle. }\end{array}$ \\
\hline
\end{tabular}




\begin{tabular}{|c|c|c|}
\hline No. & Date & Minute \\
\hline 12 & $\stackrel{1703}{\text { April }} 7$ & $\begin{array}{l}\text { Mr. Halley borrowed a paper concerning variations, } \\
\text { formerly belonging to Mr. Hooke. }\end{array}$ \\
\hline 13 & $\begin{array}{ll}1703 \\
\text { Dec. } & 8\end{array}$ & $\begin{array}{l}\text { Mr. Halley presented his Map of the Variation to the } \\
\text { Society. }\end{array}$ \\
\hline 14 & July $^{1711} 12$ & $\begin{array}{l}\text { Transact. No. 292, it was very remarkable that the dipping } \\
\text { of the needle in the latitude of } 34^{\circ} \text { South, near the Cape of } \\
\text { Good Hope, is but } 48^{\circ} \text {, whereas going to the Eastward } 78 \mathrm{I} / 2^{\circ} \\
\text { from the Cape in the S. }\end{array}$ \\
\hline 15 & $\mathrm{Jully}^{1711} 26$ & $\begin{array}{l}\text { Dr. Halley was desired to collect all the observations which } \\
\text { have been made by the Royal Society of the Variation of the } \\
\text { Needle, in order to have them published together in the Trans- } \\
\text { actions. (Adjourned for the summer.) }\end{array}$ \\
\hline 16 & Oct. $^{1711} 18$ & $\begin{array}{l}\text { The minutes of the last meeting being read and mention } \\
\text { made of the variation of the needle, Dr. Halley was desired to } \\
\text { take the variation this Year at Gresham College, and assist in } \\
\text { fxing a new meridian in some convenient place, in the House } \\
\text { or Repository of the Society in Crane Court, against the year } \\
\text { ensuing. }\end{array}$ \\
\hline 17 & $\underset{\operatorname{March} 20}{1712}$ & $\begin{array}{l}\text { The president proposed that Dr. Halley and Mr. Hawksbee } \\
\text { should try the power of the great loadstone at several dis- } \\
\text { tances to find the true proportion of its decrease, which he be- } \\
\text { lieved would be nearer the cubes than the squares. (March } \\
\text { 27. Mr. Hawksbee alone was ordered to try the experiment.) }\end{array}$ \\
\hline 18 & $\operatorname{May}^{1712} 1$ & $\begin{array}{l}\text { A paper of the variation of the magnetic needle, observed } \\
\text { by Capt. Woods Rogers in the South Sea, was read. It was } \\
\text { delivered to Dr. Halley to peruse and consider. }\end{array}$ \\
\hline 19 & $\stackrel{1716}{\text { March } 8}$ & $\begin{array}{l}\text { Dr. Halley produced a letter from Dr. Keile to himself } \\
\text { from Oxford (on the Aurora of the 6th). }\end{array}$ \\
\hline 20 & $\stackrel{1716}{\text { March } 18}$ & $\begin{array}{l}\text { Dr. Halley proposed for a solution of this strange appear- } \\
\text { ance (of aurora borealis) that on certain occasions there may } \\
\text { arise from the body of the earth such a vapour as arises from } \\
\text { the bodies of comets and of which their tails are composed. } \\
\text { This he supposed might bear a great analogy to the electrical } \\
\text { effluvia of glass, etc., which emit such streams with great } \\
\text { violence when rubbed, and said that the greatest intervals at } \\
\text { which these lights are seen is an objection against any other } \\
\text { solution that can be offered as well as this. }\end{array}$ \\
\hline 21 & $\operatorname{May}^{1716} 24$ & $\begin{array}{l}\text { Dr. Halley reported that he had drawn a Meridian Line } \\
\text { on the stone erected in the Society's yard before the repository, } \\
\text { and that the variation was found at present to be full twelve } \\
\text { degrees. It was ordered to search the Books to see how it had } \\
\text { encreased in the years past. }\end{array}$ \\
\hline 22 & $\operatorname{May}^{1716} 31$ & $\begin{array}{l}\text { Dr. Halley read a lecture upon the late wonderful phenom- } \\
\text { enon that was seen on the } 6 \text { th of March. }\end{array}$ \\
\hline 23 & $\begin{array}{ll}1719 \\
\text { Nov. } 19\end{array}$ & $\begin{array}{l}\text { Dr. Halley-accounts of a considerable aurora borealis } \\
\text { seen in the west of England. Dr. Halley read a description of } \\
\text { the same appearance seen at the same time by himself, etc. }\end{array}$ \\
\hline
\end{tabular}




\begin{tabular}{|c|c|c|}
\hline No. & Date & Minute \\
\hline 24 & $\begin{array}{c}1719 \\
\text { Dec. }\end{array}$ & $\begin{array}{l}\text { Dr. Halley produced a paper containing some observa- } \\
\text { tions made by Capt. Cornwall upon the variations of the } \\
\text { needle in the East Indies in the years } 1707,1708 \text {, and } 1709 \text {. }\end{array}$ \\
\hline 25 & Feb. 17 & $\begin{array}{l}\text { A table of magnetical variations as they were found be- } \\
\text { tween London and Hudson's Bay by the observations of Capt. } \\
\text { Chr. Middleton between the years } 1721 \text { and } 1725 \text {, was com- } \\
\text { municated by Dr. Halley. }\end{array}$ \\
\hline 26 & $\begin{array}{l}1726 \\
\text { Nov. } 10\end{array}$ & $\begin{array}{l}\text { Dr. Halley related a material circumstance observed in } \\
\text { the late aurora borealis, which serves to confirm him in his } \\
\text { former opinion, that the magnetical effluvia of the earth are } \\
\text { concerned in the production of the phenomenon, and that was } \\
\text { from the situation of the luminous arch in the north and the } \\
\text { tendency of the motion of the stria, both which seemed to } \\
\text { have a dependence upon the magnetical virtue. He sard the } \\
\text { arch was highest in that place where it crossed the magnetical } \\
\text { meridian, and the stria had a motion with an inclination like } \\
\text { that of the magnetical dipping needle. But for the clearer } \\
\text { proof of these particulars he referred to a discourse which he } \\
\text { is now preparing to lay before the Society. }\end{array}$ \\
\hline 27 & Feb. 15 & $\begin{array}{l}\text { Dr. Halley communicated a journal of observations of } \\
\text { the variation of the compass from the } 13 \text { th February, } 1724 \text {, } \\
\text { to the 18th August, } 1727 \text {, in an East India voyage from the } \\
\text { Cape de Verd Islands to Madras and from Madras to England } \\
\text { (See March 21). }\end{array}$ \\
\hline 28 & $\begin{array}{c}1728 \\
\text { Nov. } 21\end{array}$ & $\begin{array}{l}\text { A letter from Mr. Derham was read on an aurora borealis. } \\
\text { Dr. H. upon reading this letter took occasion to confirm the } \\
\text { truth of a remark which he formerly made concerning these } \\
\text { appearances and which seems to show that this phenomenon } \\
\text { has some relation or dependence on the magnetic quality of the } \\
\text { earth, for he said that it has ever been observed since he first } \\
\text { took notice of it that the center of the luminous arch and black } \\
\text { basis always lies in the magnetical meridian, and seems to change } \\
\text { its place in the horizon as that alters, as far as can be observed. }\end{array}$ \\
\hline 29 & $\operatorname{Jan}^{1731} 21$ & $\begin{array}{l}\text { Two papers were read by Capt. Hammond to account for } \\
\text { the variation of the needle. This hypothesis is the same in all } \\
\text { its essential parts with that delivered by Dr. Halley in the } \\
\text { Phil. Trans. No. 195, printed in the year } 1692 \text {, a sight of which } \\
\text { the author confesses to have had after he had composed his } \\
\text { own theory, as also to have received some hints concerning } \\
\text { the same from Dr. Halley twenty years before he writ his dis- } \\
\text { course, and says he fell upon this hypothesis by considering a } \\
\text { certain set of observations of the variation of the needle therein } \\
\text { recited: which happens to be the very same set as is made use } \\
\text { of by Dr. Halley in that Transaction, as the ground work upon } \\
\text { which he raised his own hypothesis but he claims to give a } \\
\text { more precise determination of certain circumstances left by } \\
\text { Dr. Halley to future observation. } \\
\text { It differs from Dr. Halley's in the supposed position of } \\
\text { the poles; in considering the fixt poles as of much greater } \\
\text { strength than the moveable poles of the nucleus. }\end{array}$ \\
\hline 30 & $\begin{array}{l}1732 \\
\text { Nov. } 16\end{array}$ & $\begin{array}{l}\text { Dr. Halley communicated a paper on observations of } \\
\text { latitudes and variations taken on board the Hartford on her } \\
\text { passage from Java Head to St. Helena, A. D. 1731-2. }\end{array}$ \\
\hline 31 & \begin{tabular}{c}
\multicolumn{2}{c}{1732} \\
Dec. 14
\end{tabular} & Regarding effect of lightning on magnetic needles. \\
\hline
\end{tabular}




\section{Appendix $B$.}

The Description and Uses of a New and Correct SEA-CHAR'T of the

Western and Southern OCEAN, shewing the Variations of the Compass.

The Projection of this Chart is what is commonly called Marcator's; but from its particular Use in Navigation, ought rather to be named the Nautical; as being the only true and sufficient CHART for the Sca. It is supposed, that all such as take Charge of Ships in long Voyages, are so far acquainted with its Use, as not to need any Directions here. I shall only take the Liberty to assure the Reader, that having taken all possible Care, as well from Astronomical Observations, as Journals, to ascertain the Scituation and Form of this Chart, as to its principal Parts, and the Dimensions of the several Oceans; he is not to expect that we should descend to all the Particularities necessary for the Coaster, our Scale not permitting it. What is here properly new, is the Curve-Lines drawn over the several Seas, to shew the Degrees of the Variation of the Magnetical Ncedlc, or Sca Compass: which are design'd according to what I ny self found in the Westcrn and Southern Oceans, in a Voyage I purposely made at the Publick Charge in the Year of our Lord I700.

That this may be the better understood, the curious Mariner is desired to observe, that in this Chart the Double Line passing near Bermudas, the Cape Verdc Isles, and Saint Helena every where divides the East and West Variation in this Occan, and that on the whole Coast of Europe and Africa the Variation is Westerly, as on the more Northerly Coasts of Amcrica, but on the more Southerly Parts of America 'tis Easterly. The Degrees of Variation, or how much the Compass declines from the true Nortl on either Side is reckoned by the Number of the I,ines on each side the doulle Curve, which I call the Line of No Variation; on each fifth and tenth is distinguished in its Stroak, and numbered accordingly, so that in what Place soever your Ship is, you find the Variation by Inspection.

That this may be the fuller unclerstood, take these Fxamples. At Madera the Variation is $30 \mathrm{l} / 2 \mathrm{l} . *$ West; at Burbados $5 \mathrm{1} / 2 \mathrm{~d}$. East; at Annabon 7d. West; at Cape Race in Nerefoundland I4d. West; at the Mouth of Rio dc Plata I8d. East, \&c. And this may suffice by Way of Description.

As to the Uses of this 'Chart, they will easily be understood, especially by such as are acquainted with the Azimuth Compass, to be, to correct the Course of Ships at Sea: For if the Variation of the Compass be not allowed, all Reckonings must be so far erroneous: And in continued Cloudy Weather, or where the Mariner is not provided to observe this Variation duly, the Chart will readily sliew him what Allowances he must make for this Defatlt of his Compass, and thereby rectify his Journal.

\footnotetext{
* This is a misprint and should be $3 \mathrm{y} / 2 \mathrm{~d}$. The copy in "The English Pilot," 1737 (maps 97. C. 20), consulted at the British Museum, has been pen-corrected.-L. A. B.
} 
But this Correction of the Course is in no case so necessary as in rumning down on a Parallel East or West to hit a Port: For if being in your Latitude at the Distance of 70 or 80 Leagues, you allow not the Variation, but steer East or West by Compass, you shall fall to the Northwards or Southwards of your Port on each ig Leagues of Distance, one Mile for each Degree of Variation, which may produce very dangerous Errors, where the Variation is considerable; for. Instance, having a good Observation in Latitude $49 \mathrm{~d}$. 40m. about 80 Leag. without Scilly, and not considering that there is 8 Degrees West Variation, I steer away East by Compass for the Channel; but making my way truly $E$. $8 \mathrm{~d}$. $N$. when I come up with Scilly, instead of being 3 or 4 Leagues to the South thereof, I shall find my self as much to the Northward: And this Evil will be more or less according to the Distance you sail in the Parallel. The Rule to apply it is, That to keep your Parallel truly, you go so many Degrees to the Southward of the East, and Northward of the West, as in the West Variation; but contrariwise, so many Degrees to the Northwards of the East, and Southwards of the West, as there is East Variation.

A further Use is in many Cases to estimate the Longitude at Sea thereby; for where the Curves run nearly North and South, and are thick together, as about Cape Bona Esperance, it gives a very good Indication of the Distance of the Land to Ships come from far; for there the Variation alters a Degree to each two Degrees of Longitude nearly; as may be seen in the Chart. But in this Western Ocean, between Europe and the North America, the Curves lying nearly East and West, cannot be Serviceable for this Purpose.

This Chart, as I said, was made by Observation of the Year I700, but it must be noted, that there is a perpetual tho' slow Change in the Variation almost every where, which will make it necessary in time to alter the whole System: at present it may suffice to advertise that about $C$. Bonne Espcrance, the West Variation encreases at the Rate of about a Degree in 9 Years. In our Channel it encreases a Degree in seven Years, but slower the nearer the Equinoctial Line; as on the Guinea Coast a Degree in II or I2 Years. On the American side the West Variation alters but little; and the East Variation on the Southern America decreases, the more Southerly the faster; the Line of No Variation moving gradually towards it.

I shall need to say no more about it, but let it commend it self, and all knowing Mariners are desired to lend their Assistance and Informations, towards the perfecting of this useful Work. And if by undoubted Observations it be found in any Part defective, the Notes of it will be received with all grateful Acknowledgement, and the Chart corrected accordingly. E. HAILEY.

This CHART is to be sold by $W$. Mount, and T. Page, at the Postern on Tower-Hill. 


\section{Appendix $C$.}

The Description and Uses of a New and Correct $S E A-C H A R T$ of the Whole World, shewing the Variations of the COMPASS.

The Projection of this Cliart is what is call'd Mercator's; but from its particular Use in Narigation, ought rather to be nam'd the Nautical; as being the only True and Sufficient Chart for the Sea. It is suppos'd, that all such as take Charge of Ships in long Voyages, are so far acquainted with its Use, as not to need any Directions here. I shall only take the liberty to assure the Reader, that having taken all possible Care, as well from Astronomical Observations as Journals, to ascertain the Situation and Form of the Whole World, as to its Principal Parts, and the Dimensions of the several Oceans; $\mathrm{Hc}$ is not to expect that we should descend to all the Particularities necessary for the Coaster, our Scale not permitting it. What is here properly Neze, is the Curve Lines drawn over the several Seas, to shew the degrees of the Variation of the Magnetical Needle, or Sea-Compass: Which are design'd according to what I niy self found, in the Western and Southern Oceans, in a Voyage I purposely made at the Publick Charge, in the year of our Lord I700; or have Collected from the Comparison of several Journals of Voyages lately made in the Indian Seas, adapted to the same year.

That this may be better unclerstood, the Curious Mariner is desired to observe, that in this Chart the Doulble Line passing near Bermudas, the Cape de Verde Islcs, and St. Hclcna, every where divides the East and $W$ est Variation in this Ocean, and that on the whole Coast of Europe and Africa the Variation is Westerly, as on the more Northerly Coast of America, but on the more Southerly Parts of America 'tis Easterly. The Degrees of Variation, or how much the Compass declines from the true North on either side, is reckon'd by the Number of the Lines on each side the Double Curve, which I call the Line of No Variation; and each fifth and tenth is clistinguished in its Stroak, and numbred accordingly: So that in what Place soever your Ship is, you find the Variation by Inspection. The like is to be observed in the Indian Ocean, where the Variation is altogether Westerly, increasing till you come about the Meridian of the East - part of St. Lawrence or Madagascar (where 'tis of about two Points) and thence it decreases till you arrive on the East - Coast of China, or at the Philippine - Isles. Here another double Line on which there is No Variation divides again the West from the East Variation, that in all propability is to be met with almost all over that Immense Ocean we commonly call the South - Sea; but. I have not attempted to describe the Curves therein, wanting Accounts and Journals to ascertain the same.

In the Mediterranean the Degrees of Westerly Variation are all marked and numbred from 5 deg. at Malaga, to I2 deg. at Cyprus. In the Baltick from $8 \mathrm{dcg}$. to Io $\mathrm{deg}$. In the Red Sea from I2 $d c g$. to I6 
deg.; and in the Persian Gulf from 13 to 14 degrees, all Westerly. That this may be the fuller understood, take these Examples. At Madera the Variation is 3 deg. $1 / 2$ West; at Barbadoes 5 deg. I/2 East; at $A n$ nobon 7 deg. West; at Diego Roiz Ig deg. West; at Cape Razc in Nerwfound-land I4 deg. West; at the Mouth of Rio de Plata 18 deg. East; at Java head 2 deg. $1 / 2$ West, etc. And this may suffice by way of Description.

As to the Uses of this Chart, they will be easily understood, especially by such as are acquainted with the Azimuth Compass, to be to correct the Courses of Ships at Sea, For if the Variation of the Compass be not allowed, all Reckonings must be so far erroneous: And in continued cloudy Weather, or where the Mariner is not provided to observe this Variation duly, the Chart will readily shew him what Allowances he must make for this Defatult of his Compass, and thereby rectify his Journal.

But this Correction of the Course is in no case necessary, as in running down on a Parallel East or West to hit a Port: For if being in your Latitude, at the Distance of 70 or 80 Leagues, you allow not the Variation, but steer East or West by Compass, you shall fall to the Northwards or Southwards of your Port, on each ig Leagtres of Distance, one Mile for each Degree of Variation, which may produce very dangerous Errors, where the Variation is considerable. For instance. Having a good Observation in Latitude $49 \mathrm{deg}$. $40 \mathrm{~min}$. about 80 Leagues without Scilly, and not considering that there is 8 Degrees West Variation, I steer away East by Compass for the Channel; but making my way truly E. $8 \mathrm{deg}$. $N$. when I come up with Scilly, instead of being 3 or 4 Leagues to the South thereof, I shall find my self as much to the Northward: and this Evil will be more or less, according to the Distance you sail in the Parallel. The Rule to apply it is, That to keep your Parallel truly, you go so many Degrees to the Southward of the East, and Northreard of the West, as is the West Variation: but contrariwise, so many Degrees to the Northwards of the East, and Southwards of the West, as there is East Variation.

A further Use is in many cases to estimate the Longitude at Sea thereby; for where the Curves run nearly North and South, and are thick together, as about C. Bonne Esperance, it gives a very good Indication of the Distance of the Land, to Ships come from far; for there the Variation alters a Degree to each two Degrees of Longitude nearly; as may be seen in the Chart. But in this Western Ocean, between Europe and the North America, the Curves lying nearly East and West, cannot be serviceable for this purpose.

This Chart, as is said, was made by Observations of the Year 1700 , but it must be noted, that there is a perpetual, tho' slow Change in the Variation almost every where, which will make it necessary in time to alter the whole System: At present it may suffice to advertise, that about C. Bonne Esperance, the West Variation increases at the Rate 
of about a Degree in nine Years. In our Channel it increases a degree in Seven Years, but slower the nearer the Equinoctial Line, as on the Guiney Coast a Degree in II or I2 Years. On the American Side the West Variation alters but little; and the East Variation on the Southern America decreases, the more Southerly the faster; the Line of No $V$ ariation moving gradually towards it. In the Indian Seas, after you pass St. Lawrence, the $W^{\prime}$ est Variation is on the decrease, the faster the more Westerly and Southerly; and it is in a manner at a stand when you come to the length of Java.

I shall need to say no more about it, but let it commend it self, and all knowing MARINers are desired to lend their Assistance and Information, towards the perfecting of this Useful Work. And if by undoubted Observations it be found in any Part defective, the Notes of it will be received with all grateful Acknowledgement, and the Chart Corrected accordingly.

E. HALLEY.

This CHART is to be Sold by Richard Mount and Thomas Page, at the Postern on Tozer-Hill.*

*According to the Hamburg text, reproduced by Hellmann, "This CHART is Sold by Thomas PAGE and WILliaM Mount in Postern-Row, Tower-Hill," and on the Paris text it is stated that "This CHART is Sold by R. and W. MounT and T. PAGE, in Postern-Row, Tower-Hill." It would seem as though Richard Mount and Thomas Page were the first publishers of this World Chart and text.-I. A. B.

\section{HALLEY'S OPSERVATIONS OF THE MAGNETIC DECLINATION, 1698-1700.}

Compilid and Revisid by J. P. Ault and W. F. Wallis.

Explanation of Table and Methods.

The spelling of the ports visited by Halley's ship, the Paramour Pink, was modernized. It was thotight desirable, however, to retain Halley's dates as given by him, which apply to the old style calendar; to refer them to the new style calendar, it would be necessary to add ro days in $1698-99$ and $I I$ days in 1700 .

The latitudes and longitudes, given in the columns headed "Halley's noon position", are those as published in Halley's journal, all his reckoning being made from noon to noon. The latitude usually results from "a good observation" at noon and the longitude is obtained by reckoning from the previous noon position, except in a very few cases as described in the footnotes.

In the column headed "corrected position for place of observation", the attempt was made to obtain as correct a position as possible for the place where the magnetic declination was observed. Halley's noon latitudes, accepted as observed, were referred to the place of observation by direct interpolation. Longitudes at the various ports of call were scaled from the best maps available and the outstanding differ- 